\title{
E-Learning for Employability: A Case Study from a UK Masters Programme
}

\author{
Jenny Carter, Centre for Computational Intelligence \\ Faculty of Technology, De Montfort University \\ The Gateway, Leicester, LE1 9BH \\ E-mail: jennyc@dmu.ac.uk
}

\author{
Ian Pettit, Centre for Enhancing Learning through Technology \\ Library and Learning Services, De Montfort University \\ The Gateway, Leicester, LE1 9BH \\ E-mail: ipettit@dmu.ac.uk
}

\begin{abstract}
The MSc Intelligent Systems (IS) and the MSc Intelligent Systems and Robotics (ISR) programmes at De Montfort University are Masters level courses that are delivered both on-site and by distance learning. The courses have been running successfully on-site for 8 years and are now in the fifth year with a distance learning mode. Delivering material at a distance, especially where there is technical and practical content, presents a challenge and in this paper we focus on some of the techniques adopted to overcome these challenges. The second focus of the paper is the reasons why the students choose to study such a course and the implications they believe it has on their future employability.
\end{abstract}

\section{KEY WORDS}

Post-graduate, e-learning, employability

\section{INTRODUCTION}

The MSc Intelligent Systems (IS) and the MSc Intelligent Systems and Robotics (ISR) programmes at De Montfort University are Masters level courses that are delivered both on-site and by distance learning (DL). The courses are delivered mainly by the members of the Centre for Computational Intelligence (CCI) at De Montfort University. Their development enabled us to capitalise on the research taking place within the CCI and therefore on the strengths of the staff delivering the modules.

Each MSc consists of 8 taught modules and an independent project which is equivalent to 4 modules. Each module is worth 15 credits (7.5 ECTS). The MSc ISR includes two mobile robots modules whilst MSc IS replaces one of these with a Data Mining module as an alternative application area for those less interested in pursuing mobile robotics work. A Research Methods module is delivered in semester 1 to ensure that students are equipped with the necessary skills to carry out literature searches, write project proposals and so on; and a module titled 'Applied Computational Intelligence (CI)' enables students to pursue an appropriate area of their own interest in greater depth. An overview of the course content is shown in figure 1. In this paper we discuss the issues associated with delivering such a course at a distance and investigate the motivation of the students for embarking on such a programme. In this part we particularly consider the employability of the students. 


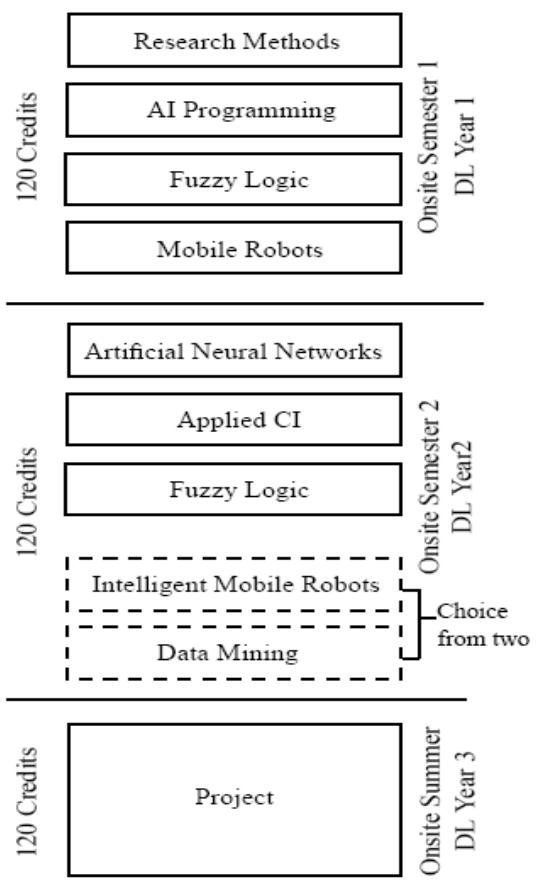

Figure 1. The course structure

The remainder of the paper is structured as follows: Section 2 discusses approaches to learning on the MSc programmes and how this fits with recognised approaches from the associated literature; Section 3 considers the e-learning provision in the Faculty of Technology; Section 4 provides a discussion of the students' perceptions of the course both in terms of its delivery and the perceived benefits on completion; and Section 5 draws conclusions from this work.

\section{APPROACHES TO LEARNING}

In order to deliver the course effectively it has been useful to consider approaches to learning and teaching in higher education more generally. Most of the modules include both theoretical and practical work and the assessments are usually open enough to allow the students to investigate appropriate topics in their own way thus there is an attempt to facilitate experiential learning as defined by [1]. We believe it to be very important for our students to draw on non-course experiences as many of them have work experience: for example, DL students are often in full time employment, there is a wide variety of first degree subjects amongst them and some already have PhDs.

We aim to adopt an approach to our delivery of the courses that embraces modern technology in such a way that the students have appropriate learning experiences whether they are studying on-site or at a distance.

The Quality Assurance Agency (QAA) for Higher education in the UK provides codes of practice for all types of learning. There is a section of the documentation that is aimed specifically at flexible and distributed learning and within this they include e-learning [2]. 
These codes of practice are observed by all higher education institutions in the United Kingdom and there are government led procedures in place to monitor their appropriate application. Precepts are stated in the QAA documentation that define what the students should be able to expect from their institution, their learning materials, their tutors and so on when engaged in flexible, distance or electronic learning.

One area of attention identified by the QAA in [3] is that of formative feedback, where students are given feedback on their work but that feedback does not relate to any marks or grades for the course or module. One of the ways that we address this is by using regular discussion board activity; this is described more fully in [4]. Another area of attention to highlight is that of plagiarism detection and prevention. We adopt various strategies for this including the use of TurnitinUK for checking authenticity and the use of vivas or presentations/demonstrations using Skype. The discussion board is also a substantial aid in both prevention and detection. In addition to this we set assignments that can be approached in a variety of ways, which reduces the opportunity for students to work too closely together. Prevention and detection of plagiarism is beyond the scope of the work presented here so will not be addressed further.

The QAA suggest that excessive amounts of summative assessment should be avoided. They state that "it is good practice to provide students with sufficient, constructive and timely feedback on their work" $[2$, p20] and this is an area that we have addressed recently. Timing has been an issue on our course as there has been a significant delay before the students receive their marked work. This is no longer the case and our approach to the solution of this is described fully in [6].

De Montfort University already uses Blackboard as a platform for providing elearning materials for all students and this is used extensively though not exhaustively in all faculties. It was therefore an obvious choice as the main platform for the MSc. Decisions about the best way to use Blackboard and which other resources to employ alongside it were necessary and as both on-site and distance students study the modules concurrently, the experiences need to be as similar as possible.

Some practices have been adopted for all modules and this includes providing some physical materials (e.g. software). We also record lectures and post them on De Montfort Universities streaming server; they can then be viewed as streamed video through Blackboard and it has proved to be a popular method. Other methods adopted include sound over Powerpoint slides using tools such as Articulate Presenter and more recently Microsoft Expression Encoder. We also provide software demonstrations using screen and voice recorders.

Assignments are made available to students on Blackboard and they are asked to submit them for assessment also to Blackboard for electronic marking. The students submit their work twice, once to TurnitinUK and once to an assignment submission link. This work is then marked using electronic methods, and the annotated scripts with provisional marks are posted in a feedback space on Blackboard that is generated when the students submit their work. Multiple files can be uploaded to this space both by students and the marking tutors. This means that the students get feedback as soon as the work is marked. 
As well as the need for feedback to be timely it also needs to be of a high quality in order for learners to be able to use it to determine further actions. This is identified in case study 4 of the Joint Information Systems Committee [JISC] [5] which states that

"feedback must:

- Be helpful, detailed and appropriate to learners’ current understanding

- Provide more detail with each failed attempt

- Identify a means of rectifying errors

- Invite an active response.“ $[5, \mathrm{p} 1]$

The report emphasises the particular importance of this with respect to DL students. Adding quality to feedback is also highlighted by [7] where studies are described that show that explanatory feedback resulted in improved learning compared with the effects of corrective feedback; explanatory feedback being where some explanation is given in the feedback when something is incorrect. The authors in [7] also go on to state that such explanations ideally should be succinct and positioned so that they are close physically to where the error in the students' work took place. Other studies, notably [8] and [9], also promote explanatory feedback by referring to it as descriptive and emphasising how it provides useful information to enable the gap to be filled between the current student performance and the desired performance. In order to offer good quality courses we aim to provide appropriate feedback that adheres to the codes of practise identified by the QAA and promotes students learning as described in the previous paragraphs.

The methods adopted for assessing the electronic submissions vary. Most tutors make use of a marking grid, an example of which is shown in Figure 2 and some staff provide summary feedback to go with the annotated grid. In such cases this forms the entire feedback and can be made available quickly. Most tutors prefer to write comments on the students' work in addition to the use of a marking grid and it is this that has posed problems in the past for returning the feedback in a timely manner. Staff now all have a pen tablet for annotating scripts electronically. With such software as Acrobat Professional, annotations on the students work can be carried out by using the typewriter tool, by hand-writing comments using the pen-tablet, by inserting electronic sticky notes or even by adding voice recordings. The number of different ways of adding feedback electronically enabled by providing this software and hardware has meant that all staff have adopted one of the electronic methods described. In [6] two modules used electronic methods for assessment and feedback as a pilot study and students opinions of the change were gathered in by means of a short survey. The results showed that all students preferred this method, even the on-site students. These results are fully reported in [6].

A consideration during the development of the course was the idea of networked learning. [10] define the term 'networked learning' to describe a particular kind of web-based or on-line learning. Their definition of networked learning is "learning in which information and communications technology is used to promote connections: between one learner and other learners; between learners and tutors; between a learning community and its resources“., It is important for us to make sure that we are not simply providing materials in a variety of forms but that the learning is networked i.e. there is human to human communication taking place within each module. 
One way that we do this is to make use of an assessed discussion board on our virtual learning environment (VLE). It is assessed based on the number of contributions over the semester rather than the quality of the content. We have found this to be very successful and it is clear that it helps to create a virtual learning community amongst our students.

Marking scheme for essay/report - worth $60 \%$ of overall mark

\begin{tabular}{|c|c|c|c|c|c|c|}
\hline & \begin{tabular}{|l|}
$0-44 \%$ \\
Fail
\end{tabular} & \begin{tabular}{|l|}
$45-49 \%$ \\
Marginal \\
Fail \\
\end{tabular} & $\begin{array}{l}50-54 \% \\
\text { Pass }\end{array}$ & $\begin{array}{l}\mathbf{5 5 - 5 9 \%} \\
\text { Pass }\end{array}$ & $\begin{array}{l}60-69 \% \\
\text { Merit }\end{array}$ & \begin{tabular}{|l|}
$>70 \%$ \\
Distinction
\end{tabular} \\
\hline $\begin{array}{l}\text { Coverage of area, } \\
\text { including } \\
\text { literature review. }\end{array}$ & \begin{tabular}{|l|} 
Not \\
acceptable
\end{tabular} & \begin{tabular}{|l|} 
Some \\
attempt to \\
cover the \\
area but with \\
serious \\
limitations.
\end{tabular} & $\begin{array}{l}\text { Bricf with } \\
\text { significant } \\
\text { limitations. }\end{array}$ & $\begin{array}{l}\text { Good } \\
\text { coverage, } \\
\text { but with } \\
\text { some } \\
\text { notable } \\
\text { limitations. }\end{array}$ & $\begin{array}{l}\text { Very good } \\
\text { coverage of } \\
\text { area and } \\
\text { associated } \\
\text { issues with } \\
\text { good review of } \\
\text { literature. }\end{array}$ & $\begin{array}{l}\text { Excellent } \\
\text { coverage, } \\
\text { showing a } \\
\text { sound } \\
\text { understanding } \\
\text { of topic. } \\
\text { Excellent } \\
\text { critical } \\
\text { review of } \\
\text { literature. }\end{array}$ \\
\hline $\begin{array}{l}\text { Practical (e.g. } \\
\text { implementation } \\
\text { or experimental } \\
\text { work) }\end{array}$ & $\begin{array}{l}\text { Very little of } \\
\text { value }\end{array}$ & $\begin{array}{l}\text { Weak, with } \\
\text { substantial } \\
\text { limitations. } \\
\text { Some effort } \\
\text { evident. }\end{array}$ & $\begin{array}{l}\text { Satisfactory } \\
\text { amount of } \\
\text { work. } \\
\text { Significant } \\
\text { limitations in } \\
\text { design \& } \\
\text { documentation. }\end{array}$ & $\begin{array}{l}\text { Good work, } \\
\text { with some } \\
\text { limitations. }\end{array}$ & $\begin{array}{l}\text { Very good } \\
\text { work, very } \\
\text { good } \\
\text { documentation } \\
\text { and design. } \\
\text { Only minor } \\
\text { limitations } \\
\end{array}$ & $\begin{array}{l}\text { Challenging } \\
\text { work, well } \\
\text { documented, } \\
\text { well designed }\end{array}$ \\
\hline $\begin{array}{l}\text { Conclusions, } \\
\text { recommendations, } \\
\text { critical } \\
\text { evaluation, new } \\
\text { ideas, etc. }\end{array}$ & $\begin{array}{l}\text { Missing or } \\
\text { poor or not } \\
\text { meaningful }\end{array}$ & \begin{tabular}{|l|} 
A minimal \\
attempt with \\
serious \\
limitations. \\
Not \\
acceptable.
\end{tabular} & $\begin{array}{l}\text { Satisfactory } \\
\text { but with } \\
\text { significant } \\
\text { limitations. }\end{array}$ & $\begin{array}{l}\text { Good, but } \\
\text { with some } \\
\text { notable } \\
\text { limitations. } \\
\text { Lacks } \\
\text { depth. }\end{array}$ & $\begin{array}{l}\text { Very good, } \\
\text { comprehensive, } \\
\text { with good } \\
\text { ideas. }\end{array}$ & $\begin{array}{l}\text { Excellent, } \\
\text { follows } \\
\text { logically } \\
\text { from body of } \\
\text { report and } \\
\text { contains } \\
\text { excellent and } \\
\text { original ideas. }\end{array}$ \\
\hline $\begin{array}{l}\text { Structure and } \\
\text { presentation. } \\
\text { References, } \\
\text { bibliography. }\end{array}$ & $\begin{array}{l}\text { No clear } \\
\text { structure, } \\
\text { and } \\
\text { presentation } \\
\text { very weak. } \\
\text { Poor or no } \\
\text { bibliography, } \\
\text { reference } \\
\text { list, citations } \\
\text { in report. }\end{array}$ & \begin{tabular}{|l|} 
Weak \\
structure \\
poor \\
presentation. \\
Poor \\
bibliography, \\
reference \\
list, citations \\
in report.
\end{tabular} & $\begin{array}{l}\text { Satisfactory } \\
\text { approach to } \\
\text { structure and } \\
\text { presentation. } \\
\text { List of } \\
\text { references } \\
\text { present but } \\
\text { with } \\
\text { significant } \\
\text { limitations. }\end{array}$ & $\begin{array}{l}\text { Well } \\
\text { structured } \\
\text { and } \\
\text { presentation } \\
\text { good. Most } \\
\text { references } \\
\text { in correct } \\
\text { format from } \\
\text { both web } \\
\text { and } \\
\text { traditional } \\
\text { sources. }\end{array}$ & $\begin{array}{l}\text { Very well } \\
\text { structured and } \\
\text { prepared with } \\
\text { only minor } \\
\text { limitations. } \\
\text { References } \\
\text { cited in correct } \\
\text { notation from } \\
\text { both web and } \\
\text { traditional } \\
\text { sources. }\end{array}$ & $\begin{array}{l}\text { Highly } \\
\text { professional } \\
\text { approach; } \\
\text { excellent } \\
\text { structure. } \\
\text { Thorough } \\
\text { reference } \\
\text { citation from } \\
\text { a variety of } \\
\text { sources. }\end{array}$ \\
\hline
\end{tabular}

Figure 2. Example marking grid

Such communities are identified as being important for student engagement in e-learning by [11]. Our experience of using this mechanism has shown that it encourages students to become more of a cohort through communicating with each other whether onsite or at a distance and it helps the distance students in particular to feel less isolated. The discussion board component is worth $10 \%$ on every module and it is this that encourages students to use it initially. We find that as they get used to using it they become more involved and often answer each other's questions and so on. Other practises used, though to a lesser extent, are blogs, which are used for keeping project journals and also as a way of putting current students in touch with past graduates from the course; a Facebook group; and more recently wikis for sharing subject related ideas and student presentations.

The next section focuses on how facilities for e-learning provision are being developed in the wider context within the Faculty of Technology and the university as a whole. 


\section{E-LEARNING PROVISION IN THE FACULTY OF TECHNOLOGY}

This section looks at E-learning provision in the Faculty of Technology.

In September 2011 De Montfort University created the Centre for Enhancing Learning through Technology (CELT) in order to take a consistent and supportive approach to ELT in the curriculum. The centre comprises of seven staff members; the Head of CELT and six Project Officers, four of whom are based in the Faculties at DMU. The centre is part of the Library and Learning Services Directorate and links closely with the Academic Professional Development Unit by way of providing support and staff development activities in the field of ELT.

Within the Faculty of Technology, the assigned CELT Project Officer works to identify and document good practice for dissemination and to support staff members in fully exploiting the situated technology, whether that is technology specifically for ELT or technology that has been provided by the central Information, Technology and Media Services (ITMS) team. There is a close relationship between ITMS and the CELT as ITMS will source and supply technology as the responsibility for provision and technical support lies with this team, however the CELT has a remit to ensure that, where pedagogically appropriate, technology that has been provided by ITMS is used to support the curriculum and to enhance the student experience fully.

Outside of this more formal arrangement, DMU does encourage staff and students to innovate the teaching and learning experience by experimenting with new and different technologies as the curriculum evolves and needs change. Part of the CELT's responsibility is to support this organic growth of innovation by acting as a critical friend and expert user in order to help test new technologies and identify and document the potential benefits or otherwise of introducing a new technology into the curriculum.

This blend of a formal agreement to support the use of situated technology in the curriculum along with encouraging experimentation with new technologies works well and is in line with the 'Core, Arranged, Recommended, Recognised' model [12] as developed by Manchester Metropolitan University and adopted by DMU.

The MSc Intelligent Systems (IS) and the MSc Intelligent Systems and Robotics (ISR) programmes showcase the way in which the CELT works to identify and share good practice and support the further innovation of teaching methods.

The good practice involving electronic marking techniques and the use of assessed Discussion Boards was documented and disseminated in spring 2012. These elements were documented by the CELT Project Officer working with the Faculty of Technology and twelve months on other staff from around the university are considering adopting these approaches for both distance learners and attending students.

During the conversations with the teaching team, other areas where technology may help to enhance the curriculum further were identified and these are being investigated at the time of writing. Such initiatives include the potential to use 3D printers to create bespoke parts for the robots in order to promote more hands on and practical activities. 
The CELT is working toward the implementation of an online hub where all of the content and resources that the CELT produces will be available on the open web for re-purposing and sharing. This hub is due to be online in February 2013. In the meantime, for further information about the Centre for Enhancing Learning through Technology please visit the DMU Learning Exchanges website [12].

The next section provides a discussion of the students' perceptions of the course both in terms of its delivery and the perceived benefits on completion.

\section{STUDENT PERCEPTIONS}

In order to find out more about the students' perspective on the course a questionnaire was sent out to 59 on-site and distance students. 15 were completed and returned at the time of writing this paper. The aim of the questionnaire was to find out the opinions of the students about the different materials that they are presented with and additionally to find out why they chose to do the course and what they hope to achieve in terms of their employability as a result of completing it.

All of the respondents to the questionnaire found out about the course through the internet and almost all of them chose to do it for either both of or one of the two same reasons, namely: career enhancement and personal interest. All of them are interested in doing research as part of or during the MSc and all but one are interested in continuing to study for a PhD. Many of our past students have gone on to do PhDs, some on-site, some in other institutions and some as distance learners.

When asked about the quality of the materials provided, there was generally positive feedback and they particularly like the videos and the sound over slides. There is still room for improvement however, as one or two modules do not offer this. The quality of some of the videos was an issue as well though the poorer quality videos have now all been replaced.

Almost all students said that they find the discussion board useful. Negative comments related to particular modules where tutor responses or feedback had not taken place regularly. Few of the respondents use the Facebook group or the e-community on Blackboard. However, evidence from Facebook itself shows that some students do use it and it also attracts past students which enables us to maintain links with graduates from the course.

Thirteen of the respondents are employed and all work in the IT field. Some see the course as a means to change direction in their employment e.g. "I hope to put it to use in the future, maybe a new job or a research position" whereas others see it as a way to develop within their current role "I expect to be able to find new solutions to problems", another student works with trading models in finance and wants to apply Computational Intelligence techniques to solve problems within that industry. Another student said "I run my own company (software) and I would like to expand (more services and products)”.

A pleasing finding is that most students agreed that they felt a sense of belonging on the MSc (10) and only 2 said that they did not. Most people do not feel isolated while studying on the course though a small number do. 


\section{CONCLUSIONS}

In this paper we have described the MSc in Intelligent Systems and MSc Intelligent Systems and Robotics. As courses that runs both on-site and by distance learning, they are often used as an example in our own institution.

Delivering courses at a distance is a topical area. With the many available mechanisms for interacting with learners electronically there are a number of choices to be made regarding the approach to take. In this paper we have described some of the approaches taken to the delivery of the learning materials and our approaches to assessment and feedback. We have also described the introduction of the CELT at De Montfort University and the Faculty of Technology's own CELT Project Officer. These are valuable assets that support the development of e-learning both in terms of trying and testing appropriate technologies but also addressing pedagogic issues that arise when delivering distance and e-materials.

Opinions about the material and the delivery methods have been gathered from students along with some information regarding their reasons for doing the course and the perceived subsequent impact on employability and career development. The students' opinions about the course are generally very positive, as are their perceptions of it as an aid to career development. The survey has highlighted some issues on a module by module basis and has given us some detailed information to work with.

The course is successful and sustainable with a total of 59 students currently enrolled ( 5 on site, the rest as distance learning). It continues to evolve as the available technologies improve; we continue to gather feedback regularly, using the responses to inform future developments. We hope to continue in this way ensuring that our students benefit from a carefully crafted course that makes appropriate use of current e-learning research and associated technology 


\section{REFERENCES}

[1] KOLB, D.: Experiential Learning: experience as the source of learning and development New Jersey: Prentice-Hall,1984

[2] QA codes of Practice, Section 2, 2010, [Online] http://www.qaa.ac.uk/academicinfrastructure/codeofpractice/default.asp

[3] QA codes of Practice, Section 6, 2006, [Online] http://www.qaa.ac.uk/academicinfrastructure/codeofpractice/default.asp

[4] Carter, J. Coupland, S., 2010, Teaching Robotics at the Postgraduate Level: Delivering for On Site and Distance Learning, Proceedings of the International Conference on Robotics in Education (RIE2010)

[5] JISC, 2010, [Online] Designing Interactive Assessments to Promote Independent Learning, http://www.jisc.ac.uk/media/documents/programmes/elearning/digiassess_interactiveasse ssments.pdf

[6] Carter, J., Matthews, S., Coupland, S. 2011, Teaching Robotics at the Postgraduate Level: Assessment \& Feedback for On Site and Distance Learning, Proceedings of the International Conference on Robotics in Education (RIE2011)

[7] Clark, R. \& Meyer R.E. ,2008, e-learning \& the science of instruction, Wiley

[8] Nicol, D. J. \& Milligan, C. (2006), Rethinking technology-supported assessment in terms of the seven principles of good feedback practice. In C. Bryan and K. Clegg (Eds), Innovative Assessment in Higher Education, Taylor and Francis Group Ltd, London

[9] Wiggins, G. (2001), Educative Assessment, San Francisco: Jossey-Bass

[10] Goodyear, P., Banks, S., Hodgson, V, McConnell, D., Advances in Research on Networked Learning, pages 1-10, Springer, 2008.

[11] Dabbagh, N.: Pedagogical Models for E-Learning: A Theory-Based Design Framework, International Journal of Technology in Teaching and Learning, 1:25-44, 2005

[12] http://www.learnex.dmu.ac.uk/e-learningdmu/dmu-core-technologies/ 